Paideusis

\title{
Aristotle and Pedagogical Ethics
}

\section{Leena Kakkori and Rauno Huttunen}

Volume 16, Number 1, 2007

URI: https://id.erudit.org/iderudit/1072603ar

DOI: https://doi.org/10.7202/1072603ar

See table of contents

Publisher(s)

Canadian Philosophy of Education Society

ISSN

0838-4517 (print)

1916-0348 (digital)

Explore this journal

Cite this article

Kakkori, L. \& Huttunen, R. (2007). Aristotle and Pedagogical Ethics. Paideusis, 16(1), 17-28. https://doi.org/10.7202/1072603ar

\section{Article abstract}

The teacher's pedagogical ethics refers to the Kantian maxims that a teacher is obliged to follow. One could provide a list of the most crucial maxims that a teacher must absolutely not violate. We surely need these Kantian maxims in the teachers' pedagogical ethics, although they tell us very little about the properties that good and moral teachers should possess. In teacher education we must of course elaborate on the ethical code of the teacher (maxims), but we must also consider the properties of a morally good teacher. A good source in endeavouring to find these properties is the book Aristotle wrote over 2,000 years ago, Nicomachean Ethics. According to Aristotle, a virtuous citizen must be educated. Without virtues (ápetń) - at least a certain degree of virtues - the polis community is impossible. Virtues are the human properties or action dispositions which facilitate the existence of telos, the purpose of a human being.” The telos of a man is to live a life worth living (eudaimon). Man achieves his telos by living a good life, which is a life lived according to certain virtues. In this article we consider what kind of a person a virtuous teacher is and what kind of a friend she is to her pupils. (c) Leena Kakkori, Rauno Huttunen, 2007

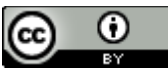

This document is protected by copyright law. Use of the services of Érudit (including reproduction) is subject to its terms and conditions, which can be viewed online.

https://apropos.erudit.org/en/users/policy-on-use/ 


\title{
Aristotle and Pedagogical Ethics
}

\author{
LEENA KAKKORI and RAUNO HUTTUNEN \\ University of Jyväskylä and University of Joensuu, Finland
}

The teacher's pedagogical ethics refers to the Kantian maxims that a teacher is obliged to follow. One could provide a list of the most crucial maxims that a teacher must absolutely not violate. We surely need these Kantian maxims in the teachers' pedagogical ethics, although they tell us very little about the properties that good and moral teachers should possess. In teacher education we must of course elaborate on the ethical code of the teacher (maxims), but we must also consider the properties of a morally good teacher. A good source in endeavouring to find these properties is the book. Aristotle wrote over 2,000 years ago, Nicomachean Ethics. According to Aristotle, a virtuous citizen must be educated. Without virtues

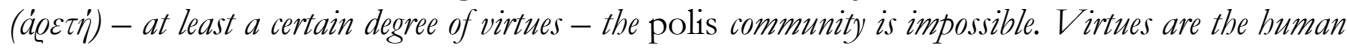
properties or action dispositions which facilitate the existence of telos, the purpose of a buman being." The telos of a man is to live a life worth living (eudaimon). Man achieves his telos by living a good life, which is a life lived according to certain virtues. In this article we consider what kind of a person a virtuous teacher is and what kind of a friend she is to her pupils.

\section{Introduction}

The new dark ages are already upon us. And if the tradition of the virtues was able to survive the horrors of the last dark ages, we are not entirely without grounds for hope. This time, however, the barbarians are not waiting beyond the frontiers; they have already been governing us for quite some time. And it is our lack of consciousness of this that constitutes part of our predicament. We are waiting not for a Godot, but for another - doubtless very different $-\mathrm{St}$ Benedict. (MacIntyre, After Virtue)

The phrase 'a teacher's pedagogical ethics' (see Kansanen, 2003; and Atjonen, 2001) refers to the Kantian maxims that teachers are obliged to follow. One could provide a list of the most crucial maxims that teachers must absolutely not violate. We surely need these kinds of Kantian maxims in the field of education; however, they ultimately tell us very little about those properties that good and moral teachers should possess. That is why we must also consider the properties of a morally good teacher or virtues of a good teacher. Aristotle's ethical writings are helpful tools in achieving this aim. The significance of Aristotle in Western thinking is hard to overestimate. A lot has been said on Aristotle in general and on his virtue ethics and his concept of friendship (filia) in particular. Nevertheless, we are going to apply Aristotle's practical philosophy to the field of education.

According to Aristotle, we must educate citizens to be virtuous. Without virtues (arete) social life in the polis is impossible. Virtues are human properties or human action dispositions which facilitate the

(C) Copyright 2007. The authors, Leena Kakeori and Rauno Huttunen, assign to Paideusis the right of first publication and educational and non-profit institutions a non-exclusive license to use this document for personal use and in courses of instruction provided that the article is used in full and this copyright statement is reproduced. Any other usage is probibited without the express permission of the authors. 
human telos, the purpose of human being. Every being has its own telos. The telos of a seed is to become a plant. The telos of a man is to live a "life worth living" (eudaimon). A life worth living means living a good life - a life lived according to virtues. A good life includes all the things that make life worth living: friends, family, a life of the mind, a political life, and pleasure and sorrow (see Nussbaum, 1998, p. 252). In order to achieve a good life, man must belong to a polis and receive an education, because without education man cannot achieve phronesis (that is, practical wisdom). A person who possesses phronesis always acts according to virtues and knows what the proper mode of action is in any given social situation.

Beside the concept of virtues, Aristotle's three concepts of friendship are very important to education. He claims that friendship lies at the very core of human life and is one of the main ingredients of happiness. The bond of friendship between citizens also constitutes the polis (city state). The crucial question nowadays is, what kind of friend teacher is with his or her pupils. We start from Aristotle's three concepts of friendship and we end up to a brand new concept of friendship called "pedagogical friendship".

\section{Aristotle on Happiness}

Happiness, then, is obviously something complete and self-sufficient, in that it is the end of what is done. (Aristotle 2000, 1097b 20 - 21)

This is Aristotle's famous argument in the first book of Nicomachean Ethics (NE), in which he defines both the goal (telos) of human being and the goal of education. Happiness (evdaimon) is the highest good of a human being. According Aristotle, every thing has its own goal. It is the most perfect way that an entity can exist. For example, the highest good of a knife is to cut well, and a sharp knife cuts better than a blunt knife. The goodness of the knife is sharpness. In this sense happiness as human telos is slightly misleading and can easily lead to misunderstandings (McDowell, 1998, p. 3 - 22).

Eudaimon is literally translated as happiness, although a more accurate translation would probably be something like "a life worth living" or "living and faring well" (Urmson, 1988, p. 11). "A life worth living" might sometimes include a great amount of sorrow and suffering, but it could still be a good life in the Aristotelian sense. A good life makes eudaimon possible. But what is a good life and what makes that possible? Aristotle concludes that three things in life can be said to contribute to the attainment of eudaimon (Aristotle, 1967, 1214a83-5): "Some people say that Wisdom is the greatest good, others Goodness [virtues], and others Pleasure." These three ways of life correspond to the following three opinions views: the life of politics, the life of philosophy, and the life of enjoyment. The philosopher's life is concerned with the contemplation of truth (ton aletheian). The politician's life is occupied with honourable activities related to the polis and requires a virtuous character. The life of hedonist is a life that enjoys the pleasures of the body (Aristotle, 1967, 1215b1-5). According to Aristotle's Eudemian Ethics, the path of a good and virtuous life is via media aurea (originally to mesos), which is a middle way between two extremes. If a life consists exclusively of politics or if the concerns of the polis play no role in life, then that it is not a good life. If a life consists solely of philosophical contemplations or there is no place for philosophy at all, it is not a good life. A life focused solely on seeking enjoyment or on the ascetic denial of any enjoyment is not a good life either ${ }^{1}$. A person is happy when he is self-sufficient and lacking nothing (Aristotle, 2000, 1097b14-6).

\footnotetext{
1 This conclusion can be drawn both from Eudeamian Ethics and book I from NE (Nicomachean Ethics), but in book $\mathrm{X}$ in NE Aristotle considers philosopher's life as perfect or highest life (Aristotle, $2000 \mathrm{X}, 1178 \mathrm{a} 2$ ). This discordance has caused a debate between two interpretations of Aristotle's concept of happiness: "dominant" versus "inclusive". The question is whether Aristotle considered eudaimon as consisting in a single activity
} 
Happiness as the highest human good is actually an activity of the soul in accordance with virtues. We acquire virtues by exercising them through education. In order to be good, a human being must have been properly educated and trained:

As we have said, then, the person who is to be good must be nobly brought up and habituated, and then spend his life engaged in good pursuits and do nothing bad whether involuntarily or voluntarily. And this would happen when people lived in accordance with a kind of intellect and a correct system with power over them. (Aristotle, 2000, 1180a15 - 16)

In other words, a person who is to be good needs to be educated through both reason and habit (see von Wright, 1964, p. 143). A human being can be neither good nor happy nor virtuous without education. The major conclusions of Aristotle's philosophy of ethics is that education is one of the most important aspects of human life.

We must be mindful that Aristotle's notion of childhood is very different than ours. Aristotle thought that it is impossible for a child to achieve happiness because, similarly to an ox or any other kind of animal, he is unable to participate in noble activities. (Aristotle, 2000, 1099b 33 - 35) We easily accept Aristotle's idea of the importance of education and we do not question the virtues of the child, because we tend to view Aristotle's philosophy through Kantian spectacles. Martha Nussbaum claims that Kant's distinction between moral and non-moral values has affected our reading of Aristotle and that our post-Kantian perspective neglects many issues on Greek ethics (Nussbaum, 1994, pp. 4 - 6). For example, our post-Kantian perspective underestimates the roles of both happiness and luck in human life. To be happy or to possess happiness is a central question in both Greek ethics in general and Aristotle's Nicomachean Ethics in particular. Thus, for the Aristotelians being happy is to be treated as an ethical question. The Kantian philosopher believes that the domain of moral value is immune to contingency and such things as luck. Whatever happens in the world, the moral value remains unaffected. Furthermore, post-Kantians and Christians think that moral value is more important than anything else. From this perspective the goodness of the human being is something quite different from the goodness of the knife. This is one major difference between post-Kantian and Aristotelian moral philosophy.

\section{Aristotle on Phronesis and the Nature of Ethical Knowledge}

Aristotle's practical ethics is based on phronesis (practical wisdom) and virtues. For Kant, "doing the right thing" means following one's duty. In Aristotle's virtue ethics there is no set of duties to which one is obliged to adhere in order to do the right thing. For Aristotle, doing the right thing means engaging in virtuous action and the use of phronesis (practical wisdom). According to Nussbaum's interpretation, phronesis is

like perceiving in the sense that it is non-inferential, non-deductive; it is, centrally, the ability to recognize, acknowledge, responds to, pick out certain salient features of a complex situation... practical perception is gained only through a long process of living and choosing that develops the agent's resourcefulness and responsiveness. (Nussbaum, 1986, p. 305)

Because phronesis arises from the multitude of experiences of concrete and particular situations and not from the knowledge of universal rules, young people cannot have phronesis (Aristotle, 2000, 1142a1216). Phronesis (practical wisdom) is also a necessary part of a good life because one cannot achieve

(philosophical contemplation) or in the exercise of several independent activities (contemplation, politics, enjoyment, having family etc.). We support inclusive interpretation. See Kenny 1992 and Hardie 1965. 
eudaimon (happiness), without the active exercise of phronesis. For Aristotle, to be human means to have this faculty of practical reasoning (Nussbaum, 1980, p. 418).

Aristotle claims that ethics as an "academic" discipline is not like mathematics. Mathematics produces exact knowledge (episteme) and general rules on unchangeable things (see Nussbaum, 1986, p. 299). Ethics, on the other hand, produces endoksa, which is not exact knowledge but the best ideas or respected opinions. Aristotle divides human thinking into three classes: theoretical thinking (theoretike), practical thinking (praktike) and productional thinking (poietike) (Aristotle, 2000, 1139a27-8). Mathematics represents theoretical thinking, and people engage in this kind of thinking for the sake of episteme itself. Practical thinking (a.k.a. ethics and political thinking) concerns the good life and its preconditions. For Aristotle, ethics cannot produce a set of rules that in themselves would guarantee a good life. Ethics can produce practical knowledge (endoksa) which is vital to the polis and its members in their efforts to achieve eudaimon. Nevertheless, this practical (ethical) knowledge alone is not sufficient in order to achieve a good life, because without the phronesis and the strength of will, practical knowledge would be useless. Aristotle says that phronesis

is not science (theoretical thinking) nor yet craft-knowledge (productional thinking). It is not science, because what is done in action admits of being otherwise; and it is not craft-knowledge, because action and production belong to different kind. The remaining possibility, then, is that intelligence (phronesis) is a state grasping the truth, involving reason, concerned with action about what is good or bad for a human being. (Aristotle, 2000, 1140b1-6)

\section{Aristotelian Virtues and the Teacher's Pedagogical Ethics}

Aristotelian virtues are dispositions with respect to a characteristic set of actions and feelings (Kosman, 1980, p. 109; see also Ollila, 1993). Virtues are dispositions to act and feel in a proper way in any given social situation. We acquire virtues by carrying out virtuous acts. We become brave by acting bravely. We become just by acting justly. One might ask how we can carry out virtuous acts unless we are already virtuous. Aristotle's reasoning might sound like a vicious circle, but it is not. Under proper parenting a child begins to carry out virtuous acts without deliberations and without possessing knowledge of the ethical nature of those acts. A child develops habitual dispositions which guide her to do "the right thing". As the process of education continues, the child comes to realises why it is desirable and sometimes even necessary to act virtuously. Likewise, bad education promotes vices and the child learns to act against the characteristics which the community considers virtuous. According to Frederick Copleston, "virtue itself is a disposition which has been developed out of a capacity by the proper exercise of that capacity" (Copleston, 1985, pp. 335-336). Aristotle says that the question of the types of habits that a child acquires is by no means unimportant - in fact, it might be the most important question of all (Aristotle, 2000, 1103b23-5; see also Comte-Sponville, 1996).

Aristotle claims that there are two forms of virtues:

Virtues, then, is of two sorts, virtue of thought and virtue of character. Virtue of thought arises and grows mostly from teaching, and hence needs experience and time. Virtue of character [ethike] result from habit [ethos]; hence its name "ethical", slightly varied from ethos. (Aristotle, 2000, 1103a15-19; see also Aristotle, 1967, 1220a4-14)

Phronesis (practical wisdom) and logiston (theoretical reason) are the virtues of thought. Phronesis is a form of wisdom concerning habits and the right conduct in social situations. Logiston is needed when considering eternal things and practising philosophical contemplation. What, then, are the virtues of character? Before presenting Aristotle's complete table of virtues of character, it is useful to keep in 
mind the history of the English word "virtue". The original Latin word is virtus, which is Marcus Tullius Cicero's translation of Aristotle's áectí (arete). Cicero translated its opposite as vitium, which is translated in English as vice (Urmson, 1988, p. 5). Later in history, virtus began to be used to refer to a devout and godly person. In the Victorian age, vitium and vice meant bad sexual morality. None of these connotations belong to the Aristotelian ethic of virtues. There is also one peculiarity in Aristotle's use of the concept of virtue. Nowadays we would say that a person that always resists temptation is a virtuous person. For Aristotle, a person who feels strong temptations and must struggle with himself before doing the right thing is not a virtuous person, though he is strong-willed. Keeping in mind these remarks, below we present the complete list of virtues of character, which is missing in Nicomachean Ethics but can be found in Eudeamian Ethics. For Aristotle, virtue of character is always a middle way between two extremes. In this table, virtue - in English and Greek - is in the middle and its extremes lie to both sides:

\begin{tabular}{|c|c|c|}
\hline Irascibility & $\begin{array}{l}\text { Gentleness } \\
\text { (Even temper) }\end{array}$ & Spiritlessness \\
\hline $\begin{array}{l}\text { Rashness } \\
\text { (Foolhardiness) }\end{array}$ & Courage & Cowardice \\
\hline Shamelessness & Modesty & $\begin{array}{l}\text { Diffidence } \\
\text { (Touchiness) }\end{array}$ \\
\hline Profligacy & Temperance & $\begin{array}{l}\text { Insensitiveness } \\
\text { (insensibility) }\end{array}$ \\
\hline Envy & $\begin{array}{l}\text { Righteous Indignation } \\
\text { (Fair-mindedness) }\end{array}$ & nameless \\
\hline Profit & The Just & Loss \\
\hline Prodigality & Liberality & Meanness \\
\hline Boastfulness & Sincerity & $\begin{array}{l}\text { Self-depreciation } \\
\text { (mock-modestv) }\end{array}$ \\
\hline Flattery & Friendliness & Surliness \\
\hline $\begin{array}{l}\text { Subservience } \\
\text { (servility) }\end{array}$ & Dignity & Stubbornness \\
\hline Luxuriousness & Hardiness & Endurance \\
\hline Vanity & Greatness of Spirit & Smallness of Spirit \\
\hline Extravagance & Magnificence & Shabbiness \\
\hline Rascality & Wisdom & Simpleness \\
\hline
\end{tabular}

Table 1. The table of virtues of character in English (Aristotle, 1967, 1220b39-1221a12; some alternative translation by Urmson, 1988, pp. 33-34 are in brackets).

\begin{tabular}{|c|c|c|}
\hline 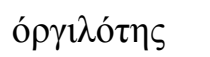 & $\pi \rho \alpha o ́ \tau \eta \varsigma$ & 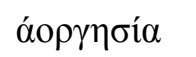 \\
\hline$\theta \rho \alpha \sigma u ́ \tau \eta \varsigma$ & 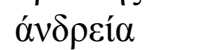 & $\delta \varepsilon \imath \lambda i \alpha$ \\
\hline 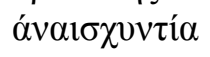 & $\alpha i \delta \omega ́ \zeta$ & $\kappa \alpha \tau \alpha \dot{\pi} \lambda \eta \xi 1 \varsigma$ \\
\hline 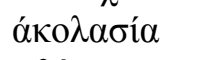 & $\sigma \omega \varphi \rho о \sigma u ́ v \eta$ & $\alpha ́ v \alpha 1 \sigma \theta \eta \sigma i \alpha$ \\
\hline$\varphi$ Өóvo $\varsigma$ & 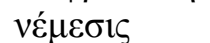 & 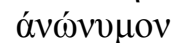 \\
\hline
\end{tabular}




\begin{tabular}{|c|c|c|}
\hline 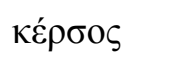 & 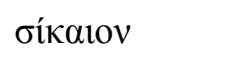 & $\zeta \eta \mu i ́ \alpha$ \\
\hline$\alpha ́ \varsigma \omega \tau i ́ \alpha$ & 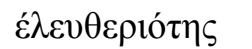 & 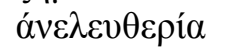 \\
\hline$\alpha ́ \lambda \alpha \zeta o v \varepsilon i ́ \alpha$ & $\alpha^{\prime} \lambda \eta \theta^{\prime} \varepsilon 1 \alpha$ & 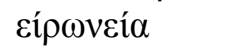 \\
\hline 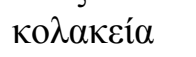 & $\varphi 1 \lambda i ́ \alpha$ & 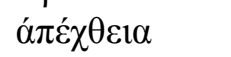 \\
\hline 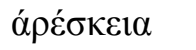 & $\sigma \varepsilon \mu v o ́ \tau \eta \varsigma$ & $\alpha v^{\theta} \theta \alpha \delta \delta$ \\
\hline$\tau \rho v \varphi \varepsilon \rho o ́ \tau \eta \varsigma$ & $\kappa \alpha \rho \tau \varepsilon \rho i ́ \alpha$ & какол $\alpha \dot{\theta \varepsilon 1 \alpha}$ \\
\hline$\chi \alpha v \vee o ́ \tau \varepsilon \varsigma$ & $\mu \varepsilon \gamma \alpha \lambda \circ \psi v \chi i ́ \alpha$ & $\mu 1 \kappa \rho о \psi v \chi \chi_{i}^{\prime} \alpha$ \\
\hline$\delta \alpha \pi \alpha v \eta \rho i ́ \alpha$ & $\mu \varepsilon \gamma \alpha \lambda \mathrm{o} \pi \rho \varepsilon \pi \varepsilon 1 \alpha$ & $\mu і \kappa \rho о \pi \rho \varepsilon \pi \varepsilon 1 \alpha$ \\
\hline$\pi \alpha v o v \rho \gamma 1 \alpha$ & $\varphi \rho o ́ v \eta \sigma i s$ & $\varepsilon v ́ \eta ́ \theta \varepsilon 1 \alpha$ \\
\hline
\end{tabular}

Table 2. The table of virtues of character in Greek (Aristotle, 1967, 1220b39-1221a12).

Here, we will focus our attention on those virtues which are relevant for the teacher. Aristotle himself did not consider teachers' virtues because teaching was not thought of as a proper task for a noble man. Our claim is that a teacher should be a virtuous person - or at least make an effort to be one - so that she could serve as an example to her pupils and choose the proper way to act in any problem situation that might occur in the classroom or academic cathedra. Nowadays we must interpret certain virtues somewhat differently than Aristotle does, but like Aristotle himself says, knowledge in ethics is not episteme (science) but endoksa, which tends to change throughout history ${ }^{2}$.

Friendliness is a trivial yet important virtue of a good teacher. A teacher should not try to flatter her students. A teacher should have such a high level of self-confidence and self-esteem that she does not have any need to either flatter or act surly. This virtue is related to Sincerity. When a teacher has high self-esteem, she has no aptitude for mock-modesty or boastful behavior. "He that pretends to have more possessions than really has is a boaster, and he that pretends to have fewer is a selfdepreciator" (Aristotle, 1967, 1221a25-8). A self-confident teacher receives recognition with a healthy sense of pride and gives honest recognition to other people. A teacher with poor self-esteem can neither receive nor give proper recognition ${ }^{3}$. Aristotle has a vice for the latter kind of character, which is diffidence. A modest person takes with dignity acknowledgement of his or her good deeds coming from others; whereas shameless person "blows one's own trumpet." This again is related to the virtue which Aristotle refers to as the greatness of spirit. A person who has greatness of spirit possesses a high level of self-esteem, as well as all the other virtues. When receiving great honours she is moderately pleased, and when receiving unjust dishonour she will entirely disdain it (Aristotle 1988, 1124a5-13). A person of great spirit does not boast and, on the other hand, does not underestimate herself. This is a very valuable characteristic in a profession in which the valuation of pupil's or student's performance is routine. According to Aristotle, "he that rates himself too high is vain, he that rates himself too low is small-spirited"(Aristotle, 1967, 1124a33-4). A person of great spirit is open in her love and hate - she hates only rightfully, which is a virtue called righteous indignation (nemesis). He or she is liberal in the sense of being generous. She or he possesses neither the characteristics of prodigality nor meanness. She or he is also prepared to accept help from others, does not hold a grudge because of past insults, and is broadminded concerning the matters of lesser importance. (Tenkku, 1981, p. 96). It would be too demanding to require that a teacher be a person who possesses greatness of spirit. We all should strive toward greatness of spirit, but in reality only a few of us will ever achieve it.

A teacher is also a leader, and good leadership demands dignity. In some sense, the teacher is a servant - in ancient Greek the teacher was literally a slave - but this does not mean that a teacher must exhibit a servile attitude. On the contrary, in order to best serve her students, a teacher must lead with

${ }^{2}$ Phronimos is a practically wise person who is able to reflect the moral good (kalon) which is "a moving target", see Owens 1991, pp. 148-149.

${ }^{3}$ How then a beginning teacher can improve his or her self-esteem, see Stanulis, Campbell \& Hicks 2002. 
dignity. This means that a teacher should not be stubborn and must be willing to listen to her students and accept criticism from them.

Gentleness, or even temper, is a very important characteristic of a good teacher. We all have school memories about hot-tempered (irascible) teachers, and we are all certainly aware of the potentially disastrous effects such a teacher can have on his or her students. Then again, a spiritless teacher does no harm, but also does no good. A good teacher must be even-tempered.

Courage is perhaps not the most important virtue of a teacher, although it is sometimes required in a teacher's work. If a teacher is afraid of her superiors and can never contradict their opinions, one is not a good teacher. A teacher must have the power to rely on his or her own judgment and the strength to resist. A teacher must have the courage to maintain order in the classroom. Of course, we must also keep the golden mean in mind when maintaining order in classroom.

Wisdom in the sense of sociability is a characteristic that is natural to teachers. A teacher cannot be a zany in the classroom, because she must keep the real rascals in order. The opposites of "zanity", simpleness or untalkativeness, are quite impossible characteristics in a good teacher.

The Just (fixaıv) in the Aristotelian meaning does not refer to social justice but to the excellence of character. In the Book IV of Nicomachean Ethics, Aristotle for some reason restricts the mean-ing of diakaion (The Just) to a middle road between profit and loss. But in Book V (which is identical to Book IV in Eudeamian Ethics), Aristotle uses the word diakaion in a broader sense. In Book V of Nicomachean Ethics, Aristotle states that "both the lawless person and the greedy and unfair person seem to be unjust; and so, clearly both the lawful and fair person will be just. Hence what is just will be both what is lawful and what is fair, and what is unjust will be both what is lawless and what is unfair" (Aristotle, 2000, 1129a33-1129b1). In this sense, of course, a teacher must be The Just. She must be lawful ${ }^{4}$ and she must be fair in her relation to both her pupils and her colleagues.

We are not convinced of the relevance of magnificence and temperance in this context. According to the ethics of duty, these characteristics are morally irrelevant or indifferent, but in Aristotelian ethics there is no such division because etbiko refers to things that are related to habits. In teachers' work, either extravagant (luxurious) dressing or aesthetic shabbiness might disturb his or her teaching. As temperate an attitude as possible toward eating, drinking, and sex is good for the teacher. Surely, if a teacher has a drinking problem he or she cannot do her job properly. If teacher is of the opinion that celibacy is the best choice for everyone, he or she is not the best person to provide sex education. With regard to temperance, the issue is how a person regards her animal soul or libido. A temperate person neither denies her animal soul nor allows it to dictate her entire personality (see Young, 1991).

We would like to add some new virtues, which were neither relevant for Aristotle nor in the lifeworld perspective in ancient Greece. I present them in the Aristotelian style of a middle way between two extremes.

\section{Authoritarian attitude Democratic attitude Laissez-faire attitude}

Democracy as the excellence of character of a teacher refers to John Dewey's concept of democracy. Democracy is not just a form of government but is an also an attitude upon which one must always reflect and improve. Of course, in schools and academic teaching situations there are a limited numbers of things that can be handled by means of democratic procedures. Nevertheless, if a teacher always makes authoritarian procedural and work-related decisions, her pupils will never learn to act in a democratic way. A teacher cannot teach democracy with an undemocratic attitude. Then again, the laissez-faire attitude is another form of an undemocratic attitude. As I mentioned before, a teacher is

\footnotetext{
${ }^{4}$ We would like to add that a teacher should be lawful to a certain extent, but for Aristotle no law is ever unjust and breaking the law is always unjust: "...it clearly follows that whatever is lawful is in some way just; for the provisions of legislative science are lawful, and we say that each of them is just." (Aristotle, 2000, 1129b12-4.). On the concept injustice in the context of education see Huttunen 2007.
} 
also a leader, and laissez-faire leadership is ill adapted to teaching both in schools and academic teaching situations. Laissez-faire leadership is a weak form of leadership and it leaves the classroom in a state of chaos in which both teaching and learning are impossible. If a teacher is a virtuous person in the Aristotelian sense, she is a strong leader, and strong leaders can also be democratic leaders. A democratic teacher also avoids indoctrinating her students. There cannot be democracy in a community in which everyone has been taught to believe in the same God, support the same political views, and share the same world view. This was actually the form of education that Aristotle himself expected the good city-state (polis) to practise.

\section{Political shamelessness}

\section{Political correctness}

\section{Political Diffidence}

This is actually a new formulation of Aristotelian virtue that is referred to as modesty. A politically correct teacher does not use racist, chauvinistic, or homophobic vocabulary. A politically shameless teacher insults her students. A politically diffident teacher is afraid to teach subjects that are politically sensitive. How does a teacher know how to act politically correctly? There are no simple rules. He or she must constantly use her phronesis and improve his or her ethical reasoning.

All in all, virtuous action and excellence of character are not things that a person can learn by reading books or listening to conference presentations. A person must possess both phronesis and a certain amount of life experience. A person acquires virtues by acting in virtuous way. A virtuous person contemplates the question of "What is a good life?" and is also aware that what oneself considers a good life is not necessarily going to be representative of a good life for the next generation. The next generation might require a different organisation of the virtues of character. Part of a good life lies in the deliberation of the concept of a good life itself and the assembling of virtues that are required in order to achieve a good life.

\section{Aristotle on Friendship}

In Aristotle's definition, friendship "is a virtue or involves virtue, and is an absolute necessity in life. No one would choose to live without friends, even if he had all the other goods." (Aristotle, 2000, 1155 a 3 - 6.) Friendship (filia) is a reciprocal relationship involving benevolence or what we might refer to as good-will. You cannot be someone's friend if he or she is not your friend, too. Friendship is reciprocal good will, and this good will must be expressed in concrete terms. Friends "must have goodwill to each other, wish good things to each other for one of the reasons given5, and not be unaware of it." (Aristotle, 2000, 1156a 3 - 5.)

We think that this reciprocity is an extremely important aspect of friendship. If I claim to be someone's friend, I am automatically implying that she shares the same feeling toward me. The expression of mere goodwill toward another person does not necessarily constitute friendship, and it would be erroneous to refer to this kind of relationship as a friendship. When we think of ethics nowadays, we would probably not even mention friendship, but for Aristotle it is one of the most important aspects of living a good and righteous life.

Aristotle notes that there are three reasons why something is worthy of being considered lovable (philetos), and the same three reasons also apply to friendship. Not everything is lovable; only those things that are good, pleasant or useful are lovable, and according to this principle there are three different kinds or types of friendship. Accordingly, the three forms of friendship are utility friendship, pleasure friendship and perfect (fine/noble/true) friendship. (Aristotle, 2000, XIII, Chapters 3 - 4.) These forms of friendships are hierarchical, the perfect or good friendship being the best form of friendship, followed by pleasure friendship and finally utility friendship.

\footnotetext{
${ }^{5}$ In the quotation "the reasons given" are goodness, pleasantness and usefulness.
} 
Here, we would like to remind the reader that friendship was something that was considered to be a virtue or like a virtue. And in order to acquire virtues one must have been educated on and have practiced this virtue. The rational part of one's soul must learn practical reason (phrosesis), which tells the irrational part of the soul how to act according to the virtue in question. And this only happens and is only attainable through practice. You do first and then you learn. A good deed is a deed that happens only by practical reason, not by accident.

In all three types of friendship, the utility (pleasure and highest form of friendship), affection and love are reciprocal to the extent that both partners are aware of it. When friendship is based on utility or pleasure, the friend is not loved as the person she is but only for the utility or pleasure that she provides to the other partner. Aristotle thinks that these kinds of friendships do not last, because once the pleasure or utility is diminished for some reason or another, the friendship diminishes, too. In all three types of friendship (the utility, pleasure and highest form of friendship), affection and love are reciprocal to the extent that both partners are aware of it. When friendship is based on utility or pleasure, the friend is not loved as the person she is but only for the utility or pleasure that she provides to the other partner. Aristotle thinks that these kinds of friendships do not last, because once the pleasure or utility is diminished for some reason or another, the friendship diminishes, too. The highest form of friendship is between good men who are similar in virtue. This can be called a true friendship, which is also the strongest type of friendship. Like the other two forms of friendship, this friendship, too, is based on a reciprocal relationship, and its partners are friends solely for the sake of the other. They wish each other well for the other's sake: not for pleasure or utility, but because they are good (kalon). This type of friendship also includes pleasantness and usefulness; however, they are not the cause of the friendship per se. They are one of the bonuses of true friendship. A true friendship can exist only between good men and equals, which is why it is extremely rare. All three forms of friendship are friendships between the same types of people; they are reciprocal relationships between equals who both get the same thing out of them. (NE 1156b 7 - 33.)

As a practical man, Aristotle was aware that most friendships are not between equals but involve a certain element of inequality between the parties. Aristotle provides examples of relationships occurring between unequal partners as including the friendships between fathers and sons, elder and younger people, husbands and wives, and friendships in general that exist between rulers and subjects. (NE 1158b 13 - 23.)

Aristotle claims that parents seem by nature to feel a sense of friendship toward their offspring and vice versa, and this friendship is between unequal parties (NE XIII 3.) Aristotle does not analyses the relations between educators and children, teachers and pupils. In fact, the entire question of who a teacher is in the Ancient world remains unanswered. The explanation to this could be that teachers were workers and not free men. Aristotle himself was a teacher or mentor of Alexander the Great, although he refrains from mentioning this experience for political reasons. To be a teacher of the King is not the same as being a teacher of das $\mathrm{Man}^{6}$, and being a teacher of lesser mortals.

\section{Friendship and the Relation between a Child and a Teacher - Introducing the Idea of Pedagogical Friendship}

As we mentioned above, most friendships are not perfect and are not between equals. Nonetheless, friends are one of the most important aspects of human life. After he poses the question of whether or not the happy man needs any friends, Aristotle answers as follows:

\footnotetext{
${ }^{6}$ Das Man belongs to the terminology of Martin Heidegger in Sein und Zeit (1986) and it means whomever you meet in the world. The opposite to this term is Dasein, the one who is always somebody, namely thyself.
} 
But it seems odd, when we assign to the happy person all good things, not to give him friends, who seem to constitute the greatest of external goods. ... For a human is a social being and his nature is to live in the company of others. So this will be the case with the happy person as well, because he possesses the natural goods, and it is clearly better to spend his days with friends and good people than with strangers or anybody he happens to bump into. So the happy person does need friends. (NE 1169b 9-11, 19-23)

The goal of education is to offer all kinds of good to the child, and this also includes the virtue of friendship. Thus, in order to acquire the virtue of friendship, the student must be educated on and practiced, which in turn requires that the teacher necessarily be a friend to her student. The question is: What kind of friend? From a modern perspective we think that we are friends to the children. But from the Aristotelian perspective this is often merely benevolence, because friendship must be reciprocal and expressed. Good-will toward someone alone is not friendship.

The friendship between teacher and student is inherently unequal, and it is very similar to the friendship between parent and child. Usually, when scholars speak on Aristotle and friendship they are referring exclusively to the highest form of friendship and not at all to other forms of friendship. This is because from our Kantian-Christian perspective it is against our worldview to think that, for example, children are less worthy than adults, or that servants are less human than non-servants, or women less worthy than men. In our society we even go so far as to consider children to be more valuable than adults. But the teacher-child relationship is unequal in the Aristotelian sense, because as an adult the teacher has more virtues and has a more extensive capacity for practical and theoretical reason than a child. This gives us some idea of the characteristics of a teacher. As a teacher, you must necessarily know something more than those whom you are teaching or educating. And thus you are not equal to your pupil. But this does not mean that you are existentially more valuable or better than your pupil. We definitely think that we must afford all humans their Kantian intrinsic value as persons and individuals despite their age, race, gender, or physical ability. Even Aristotle says that slaves have a certain value as human beings, but not as slaves.

In so far as he is a slave, then, there cannot be friendship with him. But there can be friendship in so far as he is a human being, since there does seem to be justice of some kind between any human and any other capable of community in law and agreement. So there can also be friendship, in as much as he is a human being. (NE 1161b 5 -9.)

As teachers and educators, we want to be friends to all children, and we want to provide them with all the goodness that we possibly can. But this in itself is not yet representative of a friendship; it is benevolence. Friendship needs action and reciprocity. And as we mentioned, the friendship between teacher and child is a friendship between unequal parties. When a friendship is a relationship between unequals, the partners do not receive the same thing nor get as much out of the relationship as they would in a friendship between equals. This means that teachers and children do not get as much or the same thing from friendship. "Children cannot reciprocate care equally; they require of selflessness and attention that is specific to them" (Grimshaw, 1986, p. 251). According Aristotelian thinking, this is right, because both actually get more than the other. What they get, however, is different. In the teacher-child or teacher-student relationship the teacher is in a higher position and gets more honor, while the student is in a lower position gets more benefits. We interpret this honor as a form of satisfaction one gets from one's work and is also connected to pleasure and recognition. Nevertheless, honor is not the single most important motive for a teacher; the prime motivator is love and specifically the so-called pedagogic love (see Skinnari 2004).

The friendship between teacher and child or between teacher and student does not belong to the highest form of friendship, but it has the potential to develop into a relationship that does. Here is a problem: How can the child practice the highest form of friendship, when that cannot exist between teacher and child? One answer to this problem is to introduce a new form of friendship which includes 
many elements of Aristotle's three forms of friendship. We follow Simo Skinnari's concept of pedagogical love (Skinnari, 2004) and introduce the idea of pedagogical friendship. Pedagogical love is an everyday professional and vocational feeling that the devoted teacher feels towards children. This pedagogical love is a one-sided feeling coming from teacher's side. A teacher's pedagogical love can be a foundation for pedagogical friendship which is reciprocal relationship between teacher and her pupils. Pedagogical friendship does not require equal possession of virtues of character. In this respect, it is a relationship between unequals. In this friendship partners gain utility, pleasure and a foretaste of the highest form of friendship. In this relationship children can practice and learn the highest form of friendship. Sometimes pedagogical friendship can actualize into the highest form of friendship. When this happens, pedagogical friendship ceases to exist. One famous example of how teacher-student relation develops to true friendship is from the field of philosophy; namely, the relation between Martin Heidegger and Hans-Georg Gadamer. Gadamer was first a student of Heidegger's, but later on this relation transformed into lifelong lasting friendship between two equal men and philosophers (see Grondin, 2003, pp. 294-297). The relationship started as pedagogical friendship and then transformed into highest form of friendship. When this true friendship started pedagogical relation stopped.

As conclusion, we claim the following:

1. The pedagogical friendship between teacher and child is a special kind of friendship between different kinds of partners.

2. Partners in this friendship are in a reciprocal relationship. The relationship is based on different things when we look at friendship from the perspective of the child and from the perspective of the educator. When this reciprocity does not occur, for example in large classrooms, there is only benevolence between teacher and student.

3. The highest form of friendship is not possible as long as the teacher is the teacher and the pupil is the pupil, but the aspects of the three types of friendships are still present pedagogical friendship: utility, pleasure and love.

\section{References}

Ackrill, J. (1980). 'Aristotle on Eudaimonia'. In A. Rorty (Eds.) Essays on Aristotle's Ethics. (California: University of California Press).

Arendt, H. (1989). Lectures on Kant's Political Philosophy. (Chicago: The University of Chicago Press).

Aristotle (1967). 'Athenian Constitution, Eudeamian Ethics, Virtues and Vices'. In Aristotle in twenty-three volumes, vol. XX (Greco-English edition). (Cambridge, Massachusetts: Harvard University Press).

Aristotle (2000). Nicomachean Ethics. (USA: Cambridge University Press).

Arnon, J. (1983). 'Who was Janusz Korczak?'. Inter Change, vol. 14, no. 1.

Atjonen, P. (2001). Pedagoginen etiikka [Pedagogical Ethics]. Opettaja, 14-15/2001.

Comte-Sponville, E. (1996). A Small Treatise on the Great Virtues: The Uses of Philosophy in Everyday Life. (New York: Metropolitan Books).

Copleston, F. (1985.) A History of Philosophy, Book 1, Vol. I. (New York: Doubleday).

Efron, S. (2005). 'Janusz Korczak: Legacy of a Practitioner-Researcher'. Journal of Teacher Education, Vol. 56 , no. 2.

Grimshaw, J. (1986). Philosophy and Feminist Thinking. (Minneapolis: University of Minnesota Press.

Groenhout, R.. (1998). 'The Virtue of Care: Aristotelian Ethics and Contemporary Ethics of Care'. In C. Freeland (Eds.). Feminist interpretations of Aristotle. (The Pennsylvania State University Press).

Grondin, J. (2003). Hans-Georg Gadamer - A Biography. (Yale University Press).

Hardie, W.F.R. (1965). The Final Good in Aristotle's Ethics. Philosophy, vol. 40.

Heidegger, M. (1986). Sein und Zeit. (Tübingen: Max Niemeyer). 
Huttunen, R. (2007). 'Critical Adult Education and the Political-Philosophical Debate between Nancy Fraser and Axel Honneth'. Educational Theory 3/2007.

Huttunen, R. \& Heikkinen, H.L.T. (2004). 'Teaching and the Dialectic of Recognition'. Pedagogy, Culture and Society, Vol. 12, No. 2.

Kansanen, P. (2003). 'Pedagogical Ethics in Educational Research'. Educational Research and Evaluation, Vol. 9, No. 1.

Kenny, A. (1992). Aristotle on the Perfect Life. (New York: Oxford University Press).

Kosman, L. (1980). 'Being Properly Affected: Virtues and Feelings in Aristotle's Ethics'. In A. Rorty (Eds.) Essays on Aristotle's Ethics. (California: University of California Press).

MacIntyre, A. (1981). After Virtue. (Notre Dame, Indiana: Notre Dame University Press).

McDowell, J. (1998). Mind, V alue, and Reality. (London: Harvard University Press).

Nussbaum, M. (1980). 'Shame, Separateness, and Political Unity: Aristotle's Criticism of Plato'. In A. Rorty (Eds.) Essays on Aristotle's Ethics. (California: University of California Press).

Nussbaum, M. (1994). The Fragility of Goodness. (Cambridge University Press).

Ollila, M.-R.. (1993). The Ethics of Rendevous: Morality, Virtues and Love. (Helsinki: Societas Philosophica Fennica.

Owen, J. (1991. 'Value and Practical Knowledge in Aristotle'. In J. Anton \& A. Preus (Eds.) Aristotle's Ethics. (Albany, New York: State University of New York Press).

Skinnari, S. 2004. Pedagoginen rakkaus [Pedagogical Love]. (Jyväskylä: PS-kustannus).

Stanulis, R., Nevins, C., Paige, E. \& Hicks, J. (2002). 'Finding Her Way: A Beginning Teacher's Story of Learning to Honour Her Own Voice in Teaching'. Educational Action Research, Vol. 10, No. 1.

Tenkku, J. (1981. Vanhan ja keskiajan moraalifilosofian historia [The History of Moral Philosophy in Ancient Times and the Middle Ages]. (Otaniemi: Gaudeamus).

Urmson, J. (1988). Aristotle's Ethics. (Worcester: Basil Blackwell).

von Wright, G. H. (1964). The varieties of Goodness. (London: Routledge).

Young, C. (1991). 'Aristotle on Temperance'. In J. Anton \& A. Preus (Eds.) Aristotle's Ethics. (Albany, New York: State University of New York Press).

\section{About the Authors}

Dr. Leena Kakkori is an Assistant Professor of Philosophy in the Department of Social Sciences and Philosophy, at the University of Jyväskylä, Finland. She has presented a doctoral thesis on Martin Heidegger in 2001.

Dr. Rauno Huttunen is the Docent of Philosophy of Education in the Faculty of Social Sciences, at the University of Jyväskylä, Finland. He is working as a Senior Researcher, engaged in the methodological and theoretical foundation of educational research, in the Department of Education, at the University of Jyväskylä. See webpage: joyx.joensuu.fi/ rhuttun/jkl/index_eng.html 